\title{
Luteococcus sanguinis sp. nov., isolated from human blood
}

Correspondence

Matthew D. Collins

m.d.collins@reading.ac.uk

\author{
Matthew D. Collins, ${ }^{1}$ Roger A. Hutson, ${ }^{1}$ Natalia Nikolaitchouk, ${ }^{2}$ \\ Anders Nyberg ${ }^{3}$ and Enevold Falsen ${ }^{2}$ \\ ${ }^{1}$ School of Food Biosciences, University of Reading, Reading, UK \\ ${ }^{2}$ Culture Collection, Department of Clinical Bacteriology, University of Göteborg, Göteborg, \\ Sweden \\ ${ }^{3}$ Laboratory of Clinical Bacteriology, Sundsvall Hospital, Sundsvall, Sweden
}

\begin{abstract}
An unusual catalase-positive, Gram-positive, coccus-shaped bacterium that originated from a human blood specimen was subjected to a polyphasic taxonomic study. Cell-wall murein and lipid composition analyses indicated that the unknown isolate was a member of the genus Luteococcus. The results of comparative 16S rRNA gene sequence analysis were consistent with chemotaxonomic findings and showed that the unidentified bacterium represents a hitherto unknown sublineage within the genus Luteococcus that is closely related to, but distinct from, Luteococcus japonicus. On the basis of both phenotypic and phylogenetic evidence, it is proposed that the unknown bacterium from human blood should be classified as Luteococcus sanguinis sp. nov., with the type strain CCUG $33897^{\top}\left(=\operatorname{CIP} 107216^{\top}\right)$.
\end{abstract}

The genus Luteococcus contains two species at the time of writing: Luteococcus japonicus (type species of the genus) and Luteococcus peritonei. The genus was originally proposed by Tamura et al. (1994) to accommodate two Gram-positive, coccus-shaped bacterial strains, originally designated 'Micrococcus aurantiacus' and Micrococcus sp., which were isolated in Japan from soil on Tokara Island and from water used for brewing 'miyamizu', respectively (Oda, 1935). These organisms differed from micrococci in that they contained LL-diaminopimelic acid (LL-DPM) in their walls and were found to represent a distinct lineage within the high-G $+\mathrm{C}$ Actinobacteria. Recently, a second rod-shaped member of the genus, $L$. peritonei, from a human clinical specimen, was described (Collins et al., 2000). Phylogenetically, L. japonicus and L. peritonei form a distinct group within the family Propionibacteriaceae (Stackebrandt et al., 1997), which embraces the genera Propionibacterium, Propioniferax and Microlunatus. Luteococci resemble most other species of this family in that they possess walls based on LL-DPM, but differ significantly in that they synthesize predominantly monounsaturated long-chain cellular fatty acids (Tamura et al., 1994). In contrast, other members of the family Propionibacteriaceae produce major amounts of iso- and anteisomethyl branched cellular fatty acids. In this article, we

Abbreviations: CCUG, Culture Collection of the University of Göteborg, Sweden; CIP, Collection of Bacterial Strains of the Institut Pasteur, France; LL-DPM, LL-diaminopimelic acid.

The GenBank/EMBL/DDBJ accession number for the 16S rRNA gene sequence of strain CCUG $33897^{\top}$ is AJ416758. report the results of a polyphasic taxonomic study of an unusual coccus-shaped organism isolated from a human blood culture, which resembles luteococci in that it contains exceptionally high levels of monounsaturated long-chain fatty acids. On the basis of biochemical and chemical criteria and the results of $16 \mathrm{~S}$ rRNA gene sequence analysis, we conclude that the unknown isolate represents a third species of the genus Luteococcus, for which the name Luteococcus sanguinis sp. nov. is proposed.

Strain CCUG $33897^{\mathrm{T}}$ was isolated from a blood sample (one out of four bottles) of a 32-year-old man and was submitted to the Culture Collection of the University of Göteborg (CCUG), Sweden, for identification. No other information is available on the source of the isolate. The unidentified bacterium was characterized biochemically by using the API Coryne and API ZYM systems (bioMérieux) according to the manufacturer's instructions. Cells were grown on chocolate horse blood agar (Oxoid) at $37^{\circ} \mathrm{C}$ for cellular fatty acid determination and fatty acids were examined by using the MIDI system. Cell-wall murein and lipoquinone compositions of the isolate were determined as described by Schleifer \& Kandler (1972) and Collins (1985), respectively. Phylogenetic analysis was performed by comparative 16S rRNA gene sequence analysis. A large fragment of the $16 \mathrm{~S}$ rRNA gene of the isolate was amplified by PCR, using universal primers pA (5'AGAGTTTGATCCTGGCTCAG; positions 8-27, Escherichia coli numbering) and $\mathrm{pH}^{\star}\left(5^{\prime}\right.$-AAGGAGGTGATCCAGCCGCA; positions 1541-1522) and sequenced directly by using a Taq DyeDeoxy Terminator Cycle Sequencing kit (Applied 
Biosystems) and an automatic DNA sequencer (model 373A; Applied Biosystems). The closest known relatives of the new isolate were determined by performing database searches. These sequences and those of other known related strains were retrieved from GenBank and aligned with the newly determined sequence by using the program DNATools (Rasmussen, 1995). The resulting multiple sequence alignment was corrected manually and a distance matrix was calculated with the programs PRETTY and DNADIST (using the Kimura two-parameter correction) (Felsenstein, 1989). A phylogenetic tree was constructed according to the neighbour-joining method with the program NEIGHBOR and stability of the groupings was estimated by bootstrap analysis (500 replications) by using the programs DNABOOT, DNADIST, NEIGHBOR and CONSENSE (Felsenstein, 1989). DNA-DNA reassociation experiments were carried out according to the spectrophotometric method of De Ley et al. (1970), using a Gilford System model 2600 spectrophotometer equipped with a Gilford model 2527-R thermoprogrammer and plotter.

The unidentified isolate consisted of Gram-positive, nonmotile cocci in 'bunches of grapes' formation. The strain was facultatively anaerobic and catalase-positive. When tested by using commercially available API kits, the organism produced acid from glucose, glycogen, mannitol, maltose, lactose and sucrose, but not from ribose or D-xylose. The organism reduced nitrate and hydrolysed aesculin and gelatin. Activities of acid phosphatase, alkaline phosphatase, chymotrypsin, ester lipase C8, cystine arylamidase, $\alpha$-galactosidase, $\beta$-galactosidase, $\alpha$-glucosidase, $\beta$-glucosidase, leucine arylamidase, phosphoamidase, pyrrolidonyl arylamidase, pyrazinamidase, valine arylamidase (weak reaction) and trypsin were detected. All other enzyme tests gave negative results. Analysis of cell-wall acid hydrolysates of the unknown isolate revealed LL-DPM to be the dibasic amino acid present, whilst tetrahydrogenated menaquinone with nine isoprene units $\left[\mathrm{MK}-9\left(\mathrm{H}_{4}\right)\right]$ was found to be the major respiratory quinone. This combination of chemical features is found in a number of Actinobacteria, including members of the family Propionibacteriaceae.
The long-chain cellular fatty acid composition of the unknown bacterium was examined and revealed the presence of predominantly monounsaturated fatty acid types (composition: $\mathrm{C}_{14: 0}, 0 \cdot 8 \% ; \mathrm{C}_{15: 0}, 5 \cdot 5 \% ; \mathrm{C}_{16: 0}, 2 \cdot 2 \%$; $\mathrm{C}_{17: 0}, 5 \cdot 2 \% ; \mathrm{C}_{14: 1}, 2 \cdot 2 \% ; \mathrm{C}_{15: 1}, 13 \cdot 5 \% ; \mathrm{C}_{16: 1}, 18 \% ; \mathrm{C}_{17: 1}$, $\left.45 \cdot 1 \% ; \mathrm{C}_{18: 1}, 7 \cdot 5 \%\right)$. The presence of such high levels ( $>80 \%$ ) of monounsaturated fatty acids in bacteria is very unusual, but has been reported previously in L. japonicus (Tamura et al., 1994) and L. peritonei (Collins et al., 2000).

To assess the phylogenetic position of the unknown coccus, its partial 16S rRNA gene sequence (1350 bases) was determined and subjected to comparative analysis. Sequence searches of GenBank revealed that the unknown bacterium belonged phylogenetically to the Actinobacteria and displayed a specific association with members of the Propionibacteriaceae. Highest sequence similarity was shown to $L$. japonicus $(96 \cdot 9 \%)$ and $L$. peritonei $(94 \cdot 4 \%)$. Significantly lower levels of relatedness were shown to other members of the Propionibacteriaceae [Propioniferax innocua, Microlunatus phosphovorus, Friedmanniella spp. and Propionibacterium spp. (data not shown)]. A tree constructed by using the neighbour-joining method, depicting phylogenetic relationships of the unidentified isolate, is shown in Fig. 1 and demonstrates that the isolate represents a novel sublineage within the genus Luteococcus, with $L$. japonicus as its nearest relative. Branching of strain CCUG $33897^{\mathrm{T}}$ with L. japonicus was found to be statistically significant ( $100 \%$ recovery in bootstrap resampling analysis). Given the close phylogenetic association of the unknown strain and L. japonicus, chromosomal DNA-DNA pairing was conducted on these organisms. A reassociation value of $49 \%$ was observed between isolate CCUG $33897^{\mathrm{T}}$ and the type strain of L. japonicus, thereby demonstrating that they represent different species.

Polyphasic taxonomic analysis has shown that isolate CCUG $33897^{\mathrm{T}}$, which originated from a human blood sample, represents a hitherto unrecognized species within the family Propionibacteriaceae. Long-chain fatty acids of the unknown coccus closely resemble those of species of

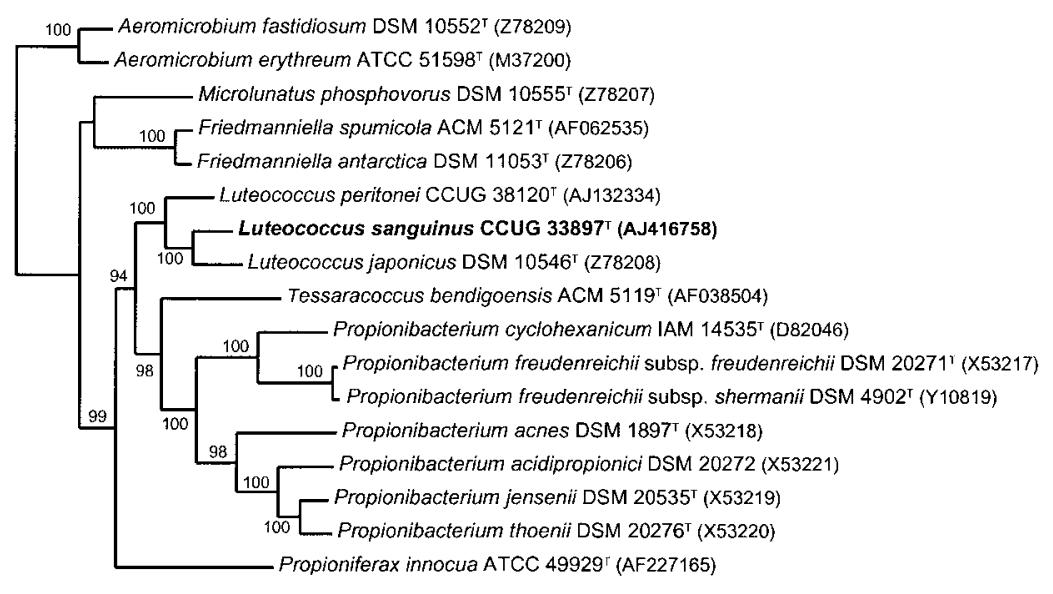

$1 \%$
Fig. 1. Unrooted tree based on $16 \mathrm{~S}$ rRNA gene sequences, showing the phylogenetic relationships of Luteococcus sanguinis $\mathrm{sp}$. nov. Numbers shown at nodes correspond to bootstrap values. Bar, $1 \%$ sequence divergence. 
the genus Luteococcus and serve to distinguish the organism from other members of the family Propionibacteriaceae (Propioniferax, Microlunatus, Friedmanniella and Propionibacterium), which synthesize major amounts of methyl branched-chain fatty acids (e.g. Pitcher \& Collins, 1991; Yokata et al., 1994; Nakamura et al., 1995; Schumann et al., 1997). Treeing analysis of $16 \mathrm{~S}$ rRNA gene sequence data supports the assignment of the unknown coccus to the genus Luteococcus. Both sequence divergence values and branching pattern considerations show that the unidentified organism is related more closely to L. japonicus than to $L$. peritonei. However, $3 \%$ sequence difference between the 16S rRNA genes of the clinical isolate and L. japonicus demonstrates that these organisms represent separate species, a conclusion that is supported by chromosomal DNA-DNA pairing. Support for the separateness of the blood isolate comes also from its distinct biochemical characteristics. In particular, the production of API Coryne profile 7552177 readily serves to distinguish the blood isolate from $L$. japonicus and $L$. peritonei, which display profiles 6572375 and 3752377, respectively. Therefore, based on biochemical, molecular chemical and molecular genetic evidence, we propose that isolate CCUG $33897^{\mathrm{T}}$ from blood should be classified in the genus Luteococcus as Luteococcus sanguinis $\mathrm{sp}$. nov.

\section{Description of Luteococcus sanguinis sp. nov.}

Luteococcus sanguinis (san'gui.nis. L. gen. n. sanguinis of blood).

Non-motile, Gram-positive cocci. Facultatively anaerobic and catalase-positive. Acid is produced from glucose, glycogen, mannitol, maltose, lactose and sucrose, but not from ribose or D-xylose. Aesculin and gelatin are hydrolysed. When tested by using commercial API Coryne and API ZYM systems, acid phosphatase (weak reaction), alkaline phosphatase, chymotrypsin, ester lipase C8 (weak), cystine arylamidase (weak), $\alpha$-galactosidase, $\beta$-galactosidase, $\alpha$-glucosidase, $\beta$-glucosidase, leucine arylamidase, phosphoamidase (weak), pyrrolidonyl arylamidase, pyrazinamidase, valine arylamidase (weak) and trypsin are detected. Esterase C4, lipase C14, $\alpha$-fucosidase, $\beta$-glucuronidase, $N$-acetyl$\beta$-glucosaminidase, $\alpha$-mannosidase, pyroglutamic acid arylamidase and urease are not detected. Voges-Proskauer reaction is negative. Nitrate is reduced to nitrite. Cell wall contains LL-DPM. Long-chain cellular fatty acids are predominantly of the monounsaturated type. MK- $9\left(\mathrm{H}_{4}\right)$ is the major menaquinone. DNA G $+\mathrm{C}$ content is $64 \mathrm{~mol} \%$.
The type strain is CCUG $33897^{\mathrm{T}}\left(=\mathrm{CIP} 107216^{\mathrm{T}}\right)$. Habitat is not known. Isolated from human blood. Pathogenic potential is not known.

\section{References}

Collins, M. D. (1985). Analysis of isoprenoid quinones. Methods Microbiol 18, 329-366.

Collins, M. D., Lawson, P. A., Nikolaitchouk, N. \& Falsen, E. (2000). Luteococcus peritonei sp. nov., isolated from the human peritoneum. Int J Syst Evol Microbiol 50, 179-181.

De Ley, J., Cattoir, H. \& Reynaerts, A. (1970). The quantitative measurement of DNA hybridization from renaturation rates. Eur $J$ Biochem 12, 133-142.

Felsenstein, J. (1989). PHYLIP - Phylogeny inference package (version 3.2). Cladistics 5, 164-166.

Nakamura, K., Hiraishi, A., Yoshimi, Y., Kawaharasaki, M., Masuda, K. \& Kamagata, Y. (1995). Microlunatus phosphovorus gen. nov., sp. nov., a new gram-positive polyphosphate-accumulating bacterium isolated from activated sludge. Int J Syst Bacteriol 45, $17-22$

Oda, M. (1935). Bacteriological studies on water used for brewing sake (part 6). I. Bacteriological studies on "miyamizu". Micrococcus and Actinomyces isolated from "miyamizu". Jozogaku Zasshi 13, 1202-1228 (in Japanese).

Pitcher, D. G. \& Collins, M. D. (1991). Phylogenetic analysis of some LL-diaminopimelic acid-containing coryneform bacteria from human skin: description of Propionibacterium innocuum sp. nov. FEMS Microbiol Lett 84, 295-300.

Rasmussen, S. W. (1995). DNATools, a software package for DNA sequence analysis. Carlsberg Laboratory, Copenhagen.

Schleifer, K. H. \& Kandler, O. (1972). Peptidoglycan types of bacterial cell walls and their taxonomic implications. Bacteriol Rev 36, 407-477.

Schumann, P., Prauser, H., Rainey, F. A., Stackebrandt, E. \& Hirsch, P. (1997). Friedmanniella antarctica gen. nov., sp. nov., an LL-diaminopimelic acid-containing actinomycete from Antarctic sandstone. Int J Syst Bacteriol 47, 278-283.

Stackebrandt, E., Rainey, F. A. \& Ward-Rainey, N. L. (1997). Proposal for a new hierarchic classification system, Actinobacteria classis. nov. Int J Syst Bacteriol 47, 479-491.

Tamura, T., Takeuchi, M. \& Yokota, A. (1994). Luteococcus japonicus gen. nov., sp. nov., a new gram-positive coccus with LL-diaminopimelic acid in the cell wall. Int J Syst Bacteriol 44, 348-356.

Yokota, A., Tamura, T., Takeuchi, M., Weiss, N. \& Stackebrandt, E. (1994). Transfer of Propionibacterium innocuum Pitcher and Collins 1991 to Propioniferax gen. nov. as Propioniferax innocua comb. nov. Int J Syst Bacteriol 44, 579-582. 